Journal of Urban and Regional Analysis, vol. XI, 2, 2019, p. 185 - 202

https://doi.org/10.37043/JURA.2019.11.2.5

\title{
ROMANIAN URBAN AREAS: TERRITORIAL, ECONOMIC AND SOCIO-CULTURAL HALLMARKS OF THE CHINESE MINORITY
}

\author{
Irena MOCANU, Radu SĂGEATĂ, Nicoleta DAMIAN, Bianca MITRICĂ, \\ Mihaela PERSU \\ Institute of Geography, Romanian Academy, Bucharest, Romania
}

\begin{abstract}
Since 1990s, many Chinese immigrants have come to Romania and they are numbering, nowadays, 2017 people (83\% of the total legal Chinese residents live in urban areas). The aim of this paper is to analyze the territorial, economic and socio-cultural hallmarks of the Chinese minority established in the Romanian urban areas. To meet this objective, both qualitative (interviews and observations) and quantitative (selecting, structuring and valorizing the statistical raw data) methods were used. This study is important due to its multi-territorial levels approach and to its results (e.g. revealing that the economic hallmark influences and shapes the territorial traces of the Chinese minority, identifying the Chinese children as being a sort of "driving force" which would facilitate the social and linguistic integration of the Chinese minority into the Romanian society) which could support and suggest new topics for the geographical research.
\end{abstract}

Key Words: Chinese minority, urban areas, Bucharest, Romania.

\section{Introduction}

The links between the two main issues approached in this paper (the Romanian urban areas and the diverse hallmarks of the Chinese minority) are related with many topics and events. The downfall of the Communist regime in Central and Eastern Europe created the premises for closer and easier international links between the urban systems from this part of Europe and the other worldwide urban systems (Robertson 2000, McFarlane 2006, Săgeată, 2014a). The long process of forced industrialization linked with an unbalanced and unfounded general development process completed the historical and socio-economic backgrounds in which the Central and Eastern European urban systems were radically transformed (Holmén 1997). Cities polarized and oriented the various flows within the territory but their development could not compensate the industrial and demographic decline and nor the negative social consequences (Friedman 1994, Featherstone 2000). Industry, as the main factor of urbanization for almost all of Romania's cities and towns, was overcome by the tertiary sector, a phenomenon specific to the large cities which strengthened their coordinating positions in the territory (lanoş and Tălângă 1994, lanoş 2004, lanoş and Heller 2006).

Since the early 1990s, the political and economic systems have opened simultaneously, while the premises for a change in the ethnic structure of Romania was created (Ungureanu and lanoş 1996). Perceived as a bridge to Western Europe, and as an outlet for Asian products (especially from China and the Near East), Romania has become a point of immigration and transit for Asian and African fluxes of population (Alexe and Păunescu 2011). The new ethnic minorities' locations could be the result of increasing social segregation (Petsimeris 1998, Creţan and Turnock 2008) inside the urban space but also at the level of urban-rural linkages, which are dependent upon the capacity of the urban system to absorb the globalizing fluxes (Kaplan 1998, lanoş et al. 2016). Like other worldwide cities, the large Romanian cities tend to assume the attributes of cosmopolitan cities due to ethnically diversity. Inside these large cities, the development of specialist services and the large-scale assimilation of global consumerist 
goods, basically products and services which go beyond the so-called "geo-cultural spaces" (Cosgrove 1989, De Lotto 2008) were important trends (van Kempen and Özüekren 1998, Săgeată 2014b).

The international literature devoted to ethnic segregations in urban areas and to ethnic economies as a result of international migrations is rich. In particular, beginning with the last decade of the $20^{\text {th }}$ century, the incidence of such studies increased and diversified: e.g. issues of ethnic economy (Kaplan and Li 2006) and the spatial structure of the urban ethnic economy (Kaplan 1998, lanoş et al. 2016, Vesalon and Creţan, 2019), diversity in urban entrepreneurship (Baycan Levent et al. 2003), ethnic segregation of urban areas (Málovics et al. 2019, Mionel 2019) and the social integration of ethnical stigmatization groups (Creţan and Turnock 2008, Creţan and Powell 2018). Within this context, theoretical approaches about the Chinese diaspora (Li 1998, Pieke 2012, Chan and Koh 2018) and its territorial, economical (Huang 2012, Men 2012, Jacoby and Korkut 2016, Hui 2018, Vangeli 2018), geopolitical (Chun 2017, Pavlićević 2018) and socio-cultural (Zhao 2010, Huang 2011, Eyferth 2012, Yang and Ortmann 2018) hallmarks in the European adoptive cities are numerous.

\section{Chinese minority in Romania. An overview}

In 2019, Romania and the People's Republic of China celebrated $70^{\text {th }}$ years since the establishment of their diplomatic relations. Given the context of bilateral trade agreements encouraged by both countries, the officials of Romania and China paid mutual visits beginning with 1950 (according to Chen 2010, in the first half of the 1980s, more than four thousand Chinese experts came to Romania). Since 1990, many Chinese immigrants would come to Romania, currently constituting the third largest group of migrants in this country (Ondreicsik 2012). The results of the 2002 Population and Housing Census (National Institute of Statistics) revealed the Chinese minority as being registered officially in Romania (2 249 persons). According to the latest official statistics (the 2011 Population and Housing Census, National Institute of Statistics), there are 2017 Chinese who live in Romania, but their real number is by far greater, given that many of them are living here without legal forms. Wundrak (2010) quotes the Romanian Office for Immigration which advances the figure of 8253 people - four times more than the official statistics. In February 2017, the Immigration General Inspectorate announced a total of 7727 asylum-seekers from China (with $12 \%$ more than in 2015).

The Chinese minority, one of the recently established in Romania during the last three decades, has raised the interest of Romanian scientists (Păcurar 2004, Săgeată 2014c, Săgeată 2015, Săgeată 2017). Their studies complete the national scientific literature on historical minorities (e.g. Germans, Hungarians, Roma, etc.) with the approach on "new" minorities (e.g. Chinese, Arabs). Despite this trend, the academic research on the growing Chinese community is underdeveloped, focusing especially on economic aspects (Chen 2010, Wundrak 2010) and on the history of Chinese immigrants to Central European Countries and to Russia (Nyiri 2007).

This study attempts to enlarge the current body of literature by identifying and studying the territorial, economic and socio-cultural hallmarks of the Chinese minority in the Romanian urban areas. Namely, the aims of this paper are: (i) to estimate how the Romanian urban economies were influenced by the Chinese investments; (ii) to show in which ways the local urban landscape and the everyday urban life were changed by the presence of the Chinese persons and their activities; and (iii) to reveal a particular hallmark emerged from the relationships between the Chinese children and their Romanian nannies. To meet these targets, the paper firstly analyzes the Chinese minority established in the entire Romanian urban environment after 1990 (national level) and in Ilfov County and the city of Bucharest (county level), in terms of quantitative (the number of Chinese people, the size of their economic activities) and qualitative aspects (the structure of Chinese active persons by 
economic activities, the territorial concentration of Chinese persons and of some economic indicators). Secondly, as long as no direct contact with the members of the Chinese minority has been established (mainly because of the linguistic barrier), the evidences in terms of sociocultural and economic hallmarks are approached as they appear from the field research done within some parts of Bucharest (local level, in Sector 2) and from the official data-base provided by different national and local institutions. Thirdly, a special hallmark is studied, namely, the one resulted from the interaction between the Chinese children and their Romanian nannies inhabiting several streets of Tei neighborhood (Sector 2, Bucharest). This study concentrates on a specific research question: Does the Chinese minority setting within Romanian cities and towns contribute to hallmarking certain urban areas/landscapes in terms of specific territorial, economic and socio-cultural aspects?

\section{Methodology}

In order to meet the research objectives of this study, both qualitative and quantitative methods were used. The interviews and field observations as tools of qualitative research were used to explore the Chinese minority in Bucharest and its socio-cultural and territorial traces within the Romanian society. Statistical raw data were selected (from a national data-base published by the National Institute of Statistics and by different other institutions - the National Trade Register Office), structured (by different criteria, e.g. ethnicity, gender, specific economic activities, etc.) and used to construct tables with processed data, further valorised through graphs and maps (Fig. 1).

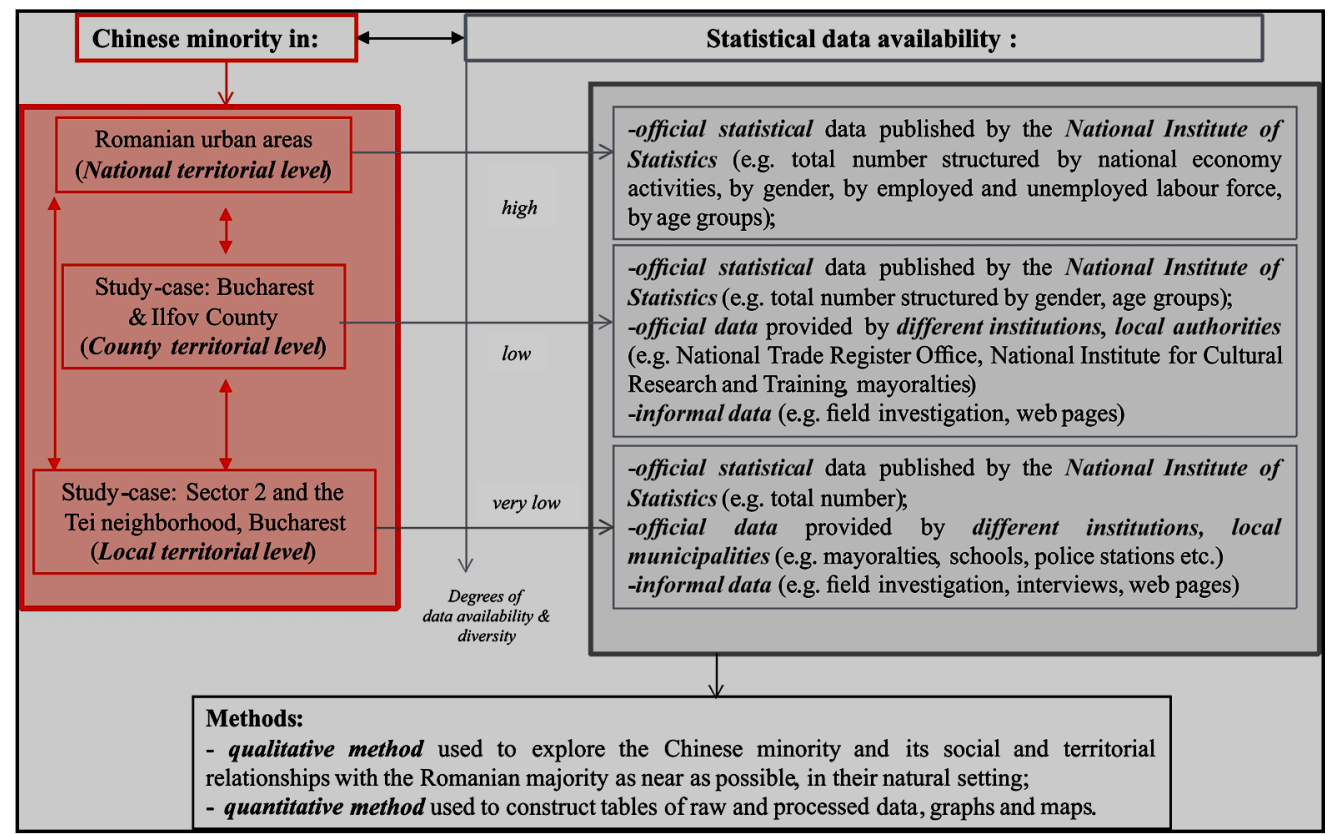

Fig. 1 - Sources of data and methods used for a multi-level territorial approach on the Chinese minority in Romania Source: authors' design 
Except for the official results of the 2002 and 2011 Population and Housing Censuses, there are few official statistical data on the Chinese population in Romania, and especially databases structured by urban and rural areas are missing. At national level, the data-base is structured into quantitative and qualitative data (e.g. by national economic activities, by gender, by the employed and the unemployed labour force, by age groups). Despite this relative diversity of statiscal data, the separate data-base on urban and rural areas presents some deficiences in terms of gender and age groups. As the territorial analysis is getting closer to the local level, the data-base is poorer. Completing these gaps, other data sources were used and valorised in this paper (e.g. the results of field investigations and interviews; other local official public documents).

The interviews were conducted in 2017 and 2018 with several local official actors of Sector 2 (Bucharest) involved in managing the issues emerged from the establishment of the new minorities in this urban area (e.g. representatives of Sector 2 Mayoralty and of local police stations, teachers and principals from kindergartens, schools and high schools, a general practitioner).

Also, some local public documents (Mayoralty of Sector 2 2017), specialized studies (Institutul Național pentru Cercetare și Formare Culturală 2015) and a project webpage (Asociaţia Mişcarea pentru Acţiune şi Iniţiativă Europeană 2015) were analyzed for extracting, interpreting and valorizing the information related to the Chinese minority in Bucharest. In view of the missing data, these informal data sources were very useful for investigating, and especially for revealing, the local socio-cultural traces of the Chinese minority.

The observation method involves systematic and long-term recording of observable interactions and/or behavior in a "natural" setting (Gorman and Clayton 2004), its main strength being that it provides direct access to the social phenomena under consideration (Salmon 2015). The unstructured observation, able to monitor all the aspects of the phenomenon that seems relevant to the problem at question (Crowther and Lancaster 2014), was used to study the interactions between the Chinese minority (e.g. Chinese children) and the Romanian majority (e.g. the nannies), but also the hallmarks between these two parts. In respect of this tool of qualitative research, the researcher's specific posture is very important. In this study, researchers had different roles during the observation: non-participation, complete observer and observer-as-participant (typology according to Adler and Adler 1994, Gorman and Clayton 2004, Baker 2006, Spradley 2016). During and after the field observation stage, another research stage consisted in writing down the field notes. In adapting and reinterpreting the sketch of field notes (Mulhall 1998, Mulhall 2003), those used for this paper tackle several aspects such as: structural and organizational features (e.g. the urban/neighborhood tissue, the street landscape), notes on the locals (e.g. ethnical groups, general behavior, inter-personal and territorial interactions, connections between the community and the local authorities), daily activities (general and ordinary population flows within the urban/neighborhood area). The field observation and interviews as tools for applying qualitative research methods are associated to some issues of ethics. Carrying out the present study has ensured the informed consent of the respondents, who were to be correctly informed on the purpose of research - the participants were informed about the use of collected data and on their privacy protection.

\section{Results and Discussion}

The Chinese - territorial and economic traces in the Romania's urban areas

The Chinese, as a new urban minority in Romania, are approached in terms of number, territorial distribution and economic features. The Chinese minority was attracted by the urban areas: in 2002, the great majority $(99 \%)$ of the legal Chinese residents was territorially concentrated in cities and towns. According to the latest official statistical data on the Chinese 
population in Romania (the 2011 Population and Housing Census), a total numer of 86 local administrative units (LAU) recorded legal Chinese residents, of which 64 LAU were urban areas (Fig. 2), cummulating 1668 Chinese people (83\% of the total legal Chinese residents), meaning that the Chinese minority is one of the most urban minorities in Romania (Schreiber et al. 2017). According to the latest official statistical data, other urban nuclei of Chinese minority in Romania are located in: Ilfov County towns (Voluntari: 359 legal Chinese residents, Pantelimon: 11 Chinese persons); Deva, Hunedoara County (27 Chinese); Arad, Arad County (21 Chinese); Timișoara, Timiş County (16 people); and in Brașov, Braşov County (14 Chinese legal residents).

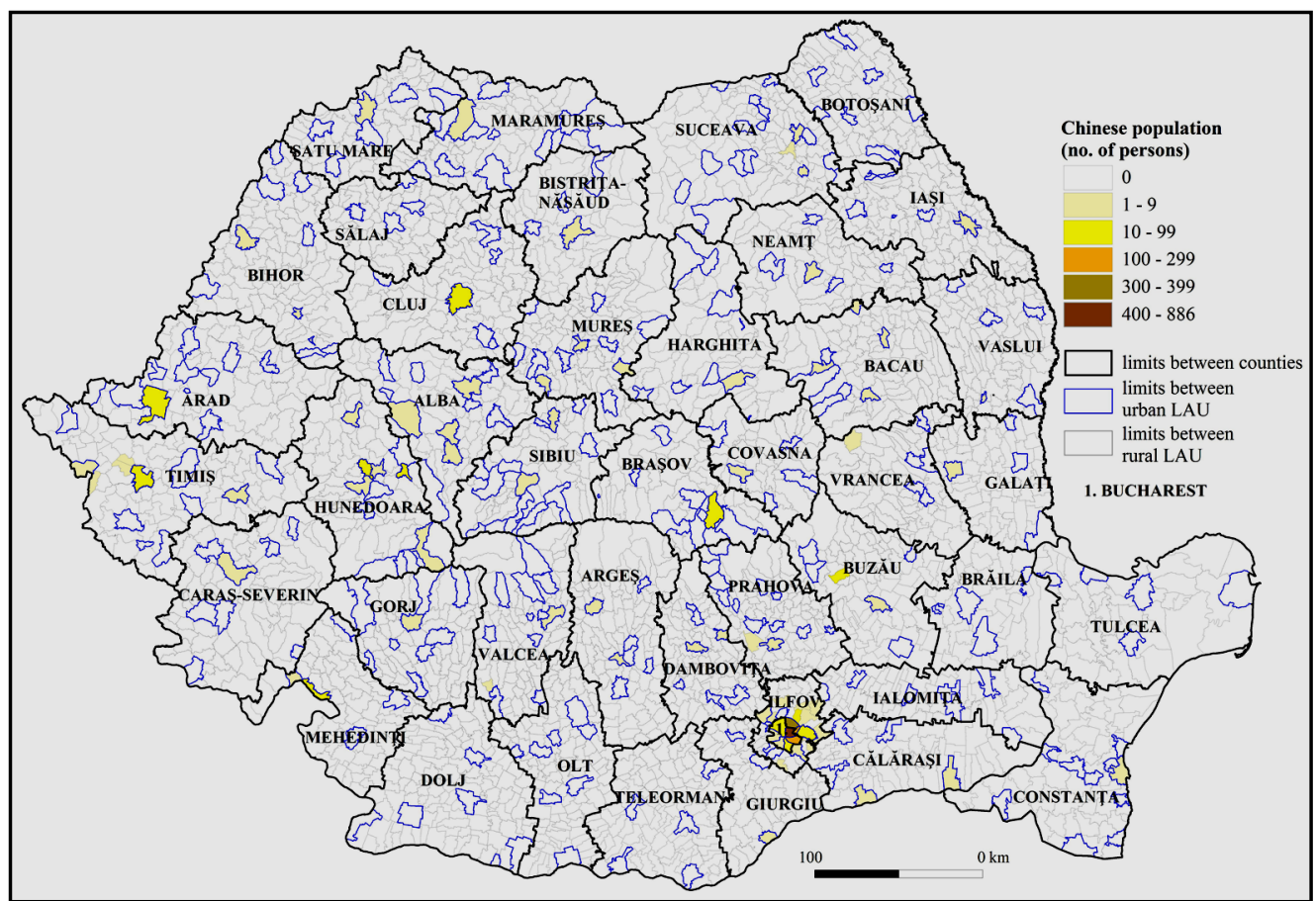

Fig. 2 - The Chinese minority in the Romanian urban and rural local administrative units (LAU)

Source: 2011 Population and Housing Census; data processed and mapped by the authors

The economic hallmarks of Chinese investments in Romania are well-known and very often revealed and positively presented by the mass-media and the politicians. The good general opinion related to the investments with Chinese involvement (e.g. they are very large, with a significant positive impact on the national and regional economies) is more the result of the media, the politicians' and the officials' attention (Drahokoupil et al. 2017). Still, Romania, together with Bulgaria, has been relatively marginal to the overall investment flows from China (McCaleb and Szunomár 2017). The deficit between Romania and China trade relationships remains a huge one: in 2011, Romanian imports amounted to some 2.5 billion Euro, six times more than the exports to China (390 million Euro). Since 2010, the commercial exchanges (both in terms of export and import flows) between Romania and China registered an upward trend, determining a total trade increase (which amounted to nearly USD 4.5 billion by the end 
of 2015 , becoming over $19 \%$ larger than in 2010) (Pencea and Oehler-Şincai 2014, Pencea 2017). According to Drahokoupil et al. (2017), because of shifting to Poland, the Czech Republic, Hungary and to some other EU member-states in the South of Europe (e.g. Portugal, Casaburi 2017), the share of Chinese investors in Romania has declined after 2005. Thus, in 2015 (according to the Chinese statistics quoted by McCaleb and Szunomár, 2017), Romania received USD 161.09 million of Chinese foreign direct investments (representing $0.83 \%$ of the total FDI). Some of the high-profile Chinese investments in Romania are: Huawei, ZTE Corp., Shantuo Agricultural Machinery Equipment, China Tobacco International Europe Company SRL, DHS (motorcycles), China Shipping, COSCO, Yuncheng Plate-Making (McCaleb and Szunomár 2017). The number of firms with Chinese capital in Romania is around $10000-$ McCaleb and Szunomár (2017) note that this value represents almost 5.6\% of the total number of commercial companies with foreign capital (the highest in the region), but most of them are small firms operating in the services or retail sectors.

According to the National Trade Register Office (ECONOMICA.net 2017), in 2016, the first 20 largest companies owned by Chinese in Romania registered a total turnover of nearly 214 million Euro (99.2\% of the total was declared by the urban Chinese companies) and a total net income of about 6.4 million Euro (of which $89.3 \%$ was produced by urban companies). These first 20 largest companies owned by the Chinese in Romania activate in the tertiary sector. In terms of turnover, these Chinese firms were located especially within cities, Bucharest and Deva (Hunedoara County) occupying the first places in the turnover hierarchy (the two cities cumulated almost $60 \%$ of the total turnover declared by the top 20 Chinese companies and also $61 \%$ of the total turnover declared by the urban Chinese firms located in Romania). In terms of net incomes, the same territorial concentration is observable: Bucharest and Deva $75 \%$ of top 20 Chinese companies of Romania, while almost $84 \%$ of top 20 Chinese firms from urban areas are active (Fig. 3 A. and B.).

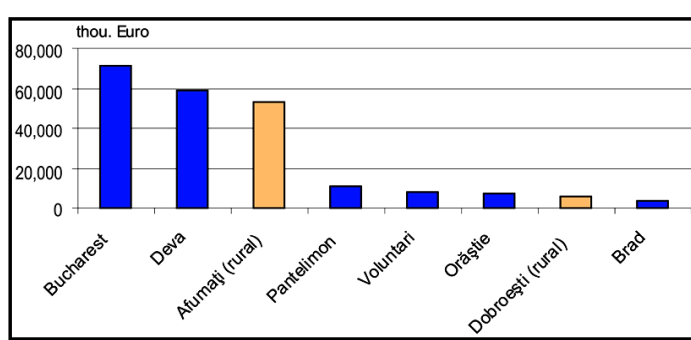

A.

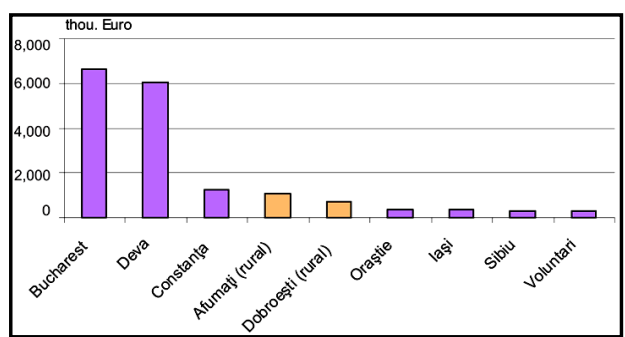

B.

Fig. 3 - The Top 20 largest companies owned by the Chinese

in Romania (territorial distribution): turnover (A.) and net income (B.) in 2016

Source: National Trade Register Office (ECONOMICA.net 2017); data processed by the authors

In the Top 20, the largest Chinese companies have firms located in towns (Pantelimon and Voluntari, in Ilfov County, appear in the Top 20 by turnover), but also in two rural settlements (Afumaţi and Dobroeşti, in Ilfov County - the Top 20 by net income), located near Bucharest. In terms of turnover, except for Bucharest (occupying the first place in Top 20 largest Chinese companies in Romania), this hierarchy is dominated by Chinese firms located in some medium towns (Deva, Hunedoara County) and small towns (Pantelimon and Voluntari, in Ilfov County; Orăştie and Brad, in Hunedoara County). One rural settlement is present in this Top 20, namely Dobroeşti (Ilfov County) registering two Chinese firms. On the contrary, in the Top 20 by the net income, there are present Chinese firms located in large Romanian cities, such as Constanţa, laşi and Sibiu.

In terms of socio-economic features, in Romanian cities and towns, a total of 1263 Chinese 
are employed while 1064 persons (84.2\% out of all) are occupied in wholesale and retail trade. Only $4.75 \%$ (85 persons) of all the Chinese employed in Romania are engaged in manufacturing and $4.2 \%$ (53 persons) in accommodation and food services. Construction, transport and storage, information and communication and real estate activities register almost $1 \%$ out of all the Chinese employed in the Romanian urban economies. In terms of the urban employment gender structure, the Chinese employed personnel (1 263 persons) is unequally divided by gender, being dominated by males: $63.8 \%$ of all the employed Chinese, $62.9 \%$ of all the Chinese employees and $65.9 \%$ of all the Chinese employers.

The effects of these Chinese investments on occupancy are not so easy to explore because of the shortcoming of statistical data. Unfortunately, the initial numbers of jobs provided in the business plans were not totally accomplished. For example, the Hoyo Chinese Company, located in Râşnov (Braşov County), with the purpose to be the main producer of agricultural machinery in Eastern Europe (an initial investment of 20 million USD, creating 500 new jobs), went bankrupt in 2017: the declared 500 jobs never existed and during the "economic boom" of Hoyo Râşnov (in 2010), only 45 new jobs were created (BizBraşov 2018). Several local and central newspapers offer examples of Chinese companies' insolvency and bankruptcy, but some positive situations are mentioned too: e.g. Huawei Romania registers 1500 employees, recording an increase of $5 \%$ of employees in all divisions (Ziarul Financiar 2017); Eurosport DHS Deva employed 400 persons recruited from Deva, Petroşani, Petrila, Hunedoara, Boşorod and Călan, all in Hunedoara County (Ziarul Financiar 2018).

\section{The Chinese in Bucharest and Ilfov County - hallmarks at regional level}

The Chinese community in Romania, established in the 1990s, settled mostly in Bucharest: 2 038 persons in 2002 and 1032 persons in 2011. The decreasing value number is a proof of the changes registered by this minority trends in territorial preferences, implicitly linked to the economic interests. Comparing the situation of 2002 to that of 2011, Bucharest remains the main urban area of territorial concentration for the Chinese, both in number of people and economic activities, but it is not anymore the single favorite city of the Chinese minority in Romania. At the beginning of 2000 s, $90.8 \%$ of all Chinese persons were living in Bucharest (concentrating $91.4 \%$ of the urban Chinese dwellers); after ten years (in 2011), only $51 \%$ of the Chinese who officially live in Romania were staying in Bucharest. An important part of the other Chinese people had chosen llfov County as their interest area in terms of dwelling and economic activities: in 2002, there were only 10 Chinese persons in this county (5 people in Buftea and 5 other people in the rural settlements of Afumaţi, Cernica, Dobroeşti and Dascălu), but, in 2011, their number increased up to 681 persons. So that, there is an important concentration of Chinese people near Bucharest, especially in Dobroeşti, a rural settlement, where 210 Chinese are registered $(2.25 \%$ of the total local population). This was the highest share of Chinese persons per total local population registered by a local territorial administrative unit in Romania (Săgeată 2017) (Fig. 4).

According to the latest Census (2011), Ilfov County and Bucharest account for $85 \%$ of all Chinese people who officially live in Romania. The unofficial data-sources (Wundrak 2010, Toader 2011) advance a three-time bigger figure: in 2010, Wundrak (2010) estimates about 3 900 Chinese people in Bucharest, while Toader (2011), in his study on the former Chinese workers who had applied for asylum in Romania, advances such figures as 1540 Chinese merchants and 1088 Chinese people looking for a job in Bucharest. According to the llfov County Statistics Office (2011), most Chinese residents are located in the town of Voluntari (359 persons) and in two rural settlements (Dobroeşti - 210 persons and Ştefăneştii de Jos 72 persons) (Săgeată 2017).

The hallmarks, in terms of time and space, of the Chinese migrant group settling in Bucharest and in Ilfov County and the reasons for the present territorial concentration of this minority are 


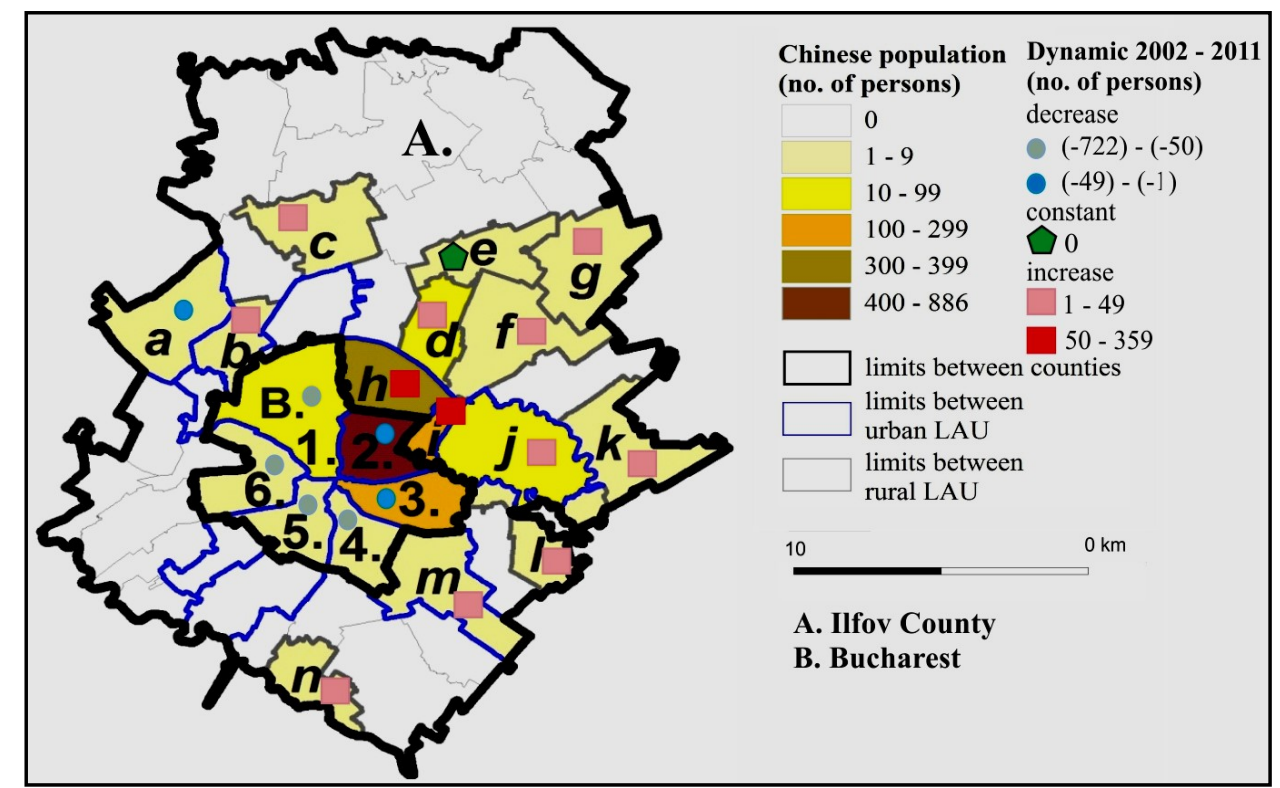

Fig. 4 - The Chinese minority in Bucharest and in Ilfov County (territorial distribution and temporal dynamics)

(Legend: $\boldsymbol{a}=$ Buftea, $\boldsymbol{b}=$ Mogoşoaia, $\boldsymbol{c}=$ Baloteşti, $\boldsymbol{d}=$ Stefăneştii de Jos, $\mathbf{e}=$ Dascălu, $\boldsymbol{f}=$ Afumaţi, $\boldsymbol{g}=$ Petrăchioaia, $\boldsymbol{h}=$ Voluntari, $\boldsymbol{i}=$ Dobroeşti, $\boldsymbol{j}=$ Pantelimon, $\boldsymbol{k}=$ Brăneşti, $\boldsymbol{l}=$ Cernica, $\boldsymbol{m}=$ Popeşti Leordeni, $\boldsymbol{n}=1$ Decembrie; 1. = Sector 1, 2. = Sector 2, 3. = Sector 3, 4. = Sector 4, 5. = Sector 5, 6. = Sector 6)

Source: 2011 Population and Housing Census; data processed and mapped by the authors

synthetically presented in Fig. 5. The authors outline the time-periods of relatively stable characteristics, considering the main occupation (i.e. trade) of Chinese immigrants in Romania since the 1990s, as the outstanding factor and socio-economic hallmark in determining their level of education, economic interests and territorial preferences.

The driving-force behind the Chinese settling in Romania was and still is of an economic nature. In the early 1990 s, the first Chinese immigrants, who were merchants, settled in Bucharest - the largest market within the country. Since then, despite the fact that the flows of Chinese merchants have not been numerically constant, yet they have always been present in Bucharest. The initial location of the Chinese merchants, inside (Colentina and Tei neighborhoods) and outside (Dobroeşti rural settlement and Pantelimon town, both in Ilfov County) Bucharest, shaped the new flows' choices. Not all Chinese merchants who came to Romania in the 1990s were successful, as in many cases they had to liquidate their firm and to go back to China (Băncilă 2010). But, generally speaking, for the small Chinese merchants who stayed in Romania, business went well and very well. During their stay in Romania, they rented apartments (some even bought them) and founded families.

The Europa trade centre in Bucharest represents the place where the Chinese have established a very profitable business (Wundrak 2007, Chen 2010). During the last decades, Europa was the first place where the Chinese merchants offered their wholesale goods to the Romanian consumers. The second one was the Red Dragon (Fig. 6), opened in 2002, at a distance of about 10 kilometers from the city centre of Bucharest, being located in Dobroeşti, Ilfov County. The Red Dragon, a simple market-seeking investment (Drahokoupil et al. 2017), 
became one of the most important trading complexes for Chinese goods in Romania, the products being distributed not only throughout the country, but also in the neighboring states Serbia, Bulgaria and the Republic of Moldova (Wundrak 2010, Ondreicsik 2012).

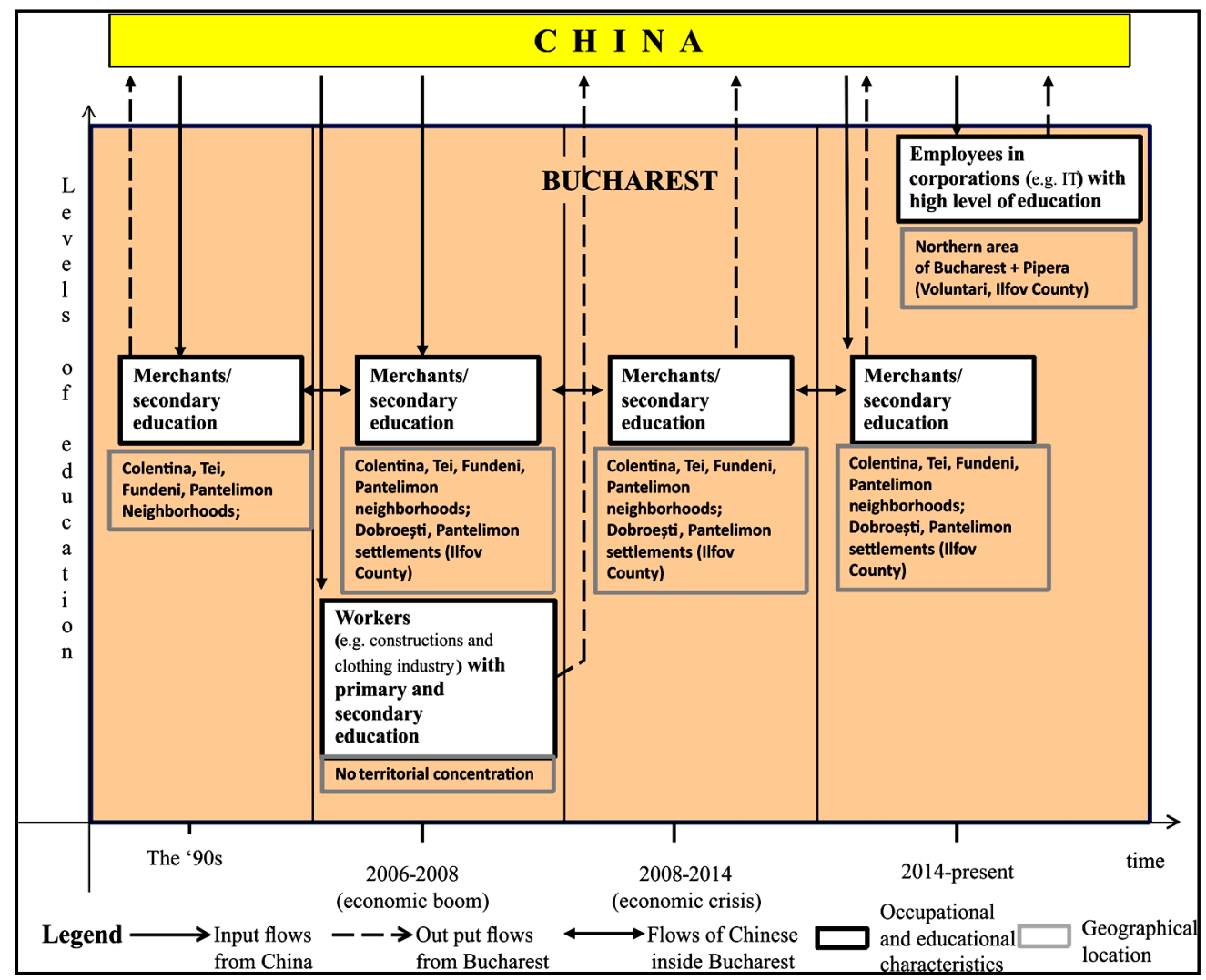

Fig. 5-Chinese occupational groups and their general educational level (temporal and territorial dynamics in Bucharest and in Ilfov County) Source: authors' design

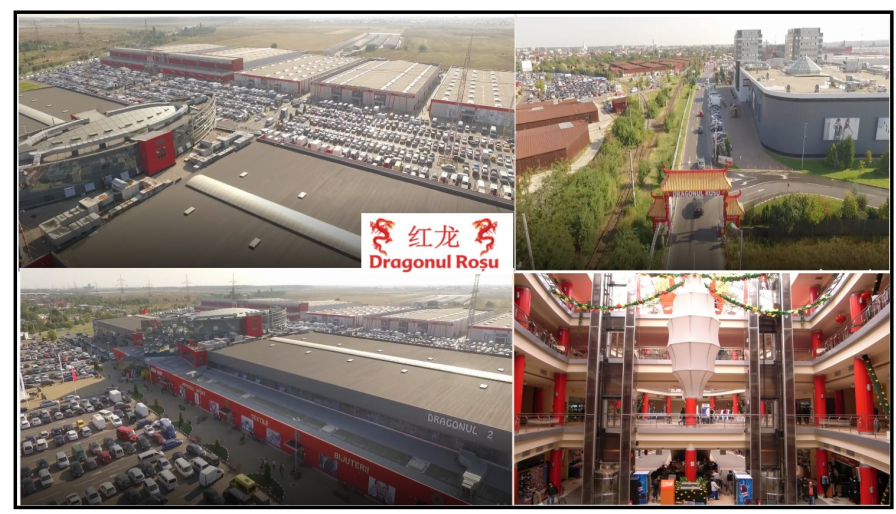

Fig. 6-The Red Dragon commercial complex territorial, economic and cultural hallmarks of the Chinese minority in Ilfov County Source: www.dragonulrosu.ro; Săgeată (2017) 
During the economic boom, new flows of Chinese immigrants joined the flow of merchants (e.g. workers in various fields, mainly in constructions and in the garment industry), settling in Bucharest and in other Romanian cities and towns and rural locations. These workers represented a cheaper labour force than the local one and a way to meet the demand for it, given the massive emigration of Romanians abroad. The workers came in compact groups from China under labour contracts with Romanian companies or with European ones operating in Romania. After the economic boom ended, the majority of female workers in the garment industry left Romania, either because their contracts had finished or the employing firms ceased/suspended their production. Also, the rising salaries in China, the language barriers, the Chinese producers' preference for US customers (who choose simpler models and a bigger production volume than the Europeans do) were other reasons for leaving Romania. Within this context, the merchants become again the most important category of Chinese immigrants established in Bucharest and in its neighboring area (Ilfov County), but also in others parts of Romania.

Starting with 2013-2014, a new flow of Chinese workforce arrived in Romania: those employed by corporations, especially in IT and telecommunications. The Chinese corporatists came to Bucharest on a contract-base concluded with the multinational companies (Asociaţia Mişcarea pentru Acţiune şi Iniţiativă Europeană 2015). These companies are mostly located in the north of the city. Generally, since they are not well integrated into Bucharest's urban life, their daily life is going on especially in the northern area of the city, living in apartments rent by the corporations, working within the companies which rent those apartments, going shopping and spending leisure time somehow confined to the north of Bucharest, the so-called "Pipera area" in the neighbouring town of Voluntari, Ilfov County. Usually, after their employment contracts come to an end, they go to another European or Asian country.

Economically, Bucharest and Ilfov County concentrated important shares of the top 20 largest companies owned by the Chinese in Romania. In terms of turnover, Bucharest (4 Chinese firms) concentrated almost $48 \%$ of the turnover declared by the Chinese firms located in Bucharest and Ilfov County; Sector 3 of Bucharest (a single Chinese firm) concentrated $48 \%$. Near Bucharest, in Afumaţi rural settlement, in 2016, the 6 Chinese companies registered $36 \%$ of the total turnover declared by the Chinese firms located in Bucharest and Ilfov County. Other territorial concentrations of Chinese firms designated by their turnover were located in Pantelimon (1 Chinese firm, $7 \%$ of the total turnover), Voluntari (3 Chinese firms, $5 \%$ of the total turnover) and Dobroeşti (2 Chinese firms, $4 \%$ of the total turnover). Generally, these Chinese companies discharge such activities as the repair of computers and communication equipment and wholesale trade, except of motor vehicles and motorcycles (Fig. 7).

Within the Top 20 Chinese firms in Romania by their net income in 2016, a total of 12 companies are located in Bucharest and in Ilfov County. A number of 3 Chinese firms located in Bucharest Sector 3, with economic activities in wholesale trade and electricity, gas, steam and air conditioning supply, cumulated $62 \%$ of the total net income registered by the Chinese companies located in Bucharest and Ilfov County.

\section{The Chinese minority in Sector 2, Bucharest - territorial, economic} and socio-cultural hallmarks at local level

From the administrative and statistical viewpoints, Bucharest is divided into six sectors. The Chinese are concentrated in Sector 2 (located in the north-eastern part of the city), where 886 Chinese persons ( $85 \%$ of all those who live in the Capital city) were registered. The National Institute for Cultural Research and Training (Institutul Național pentru Cercetare și Formare Culturală 2015) made a study on multiculturalism devoted to ethnical minority groups, based on the inhabitants' participation in cultural events. In terms of the locals' cultural involvement 
(Mayoralty of Sector 2 2017), Sector 2 ranks the first $(2.4 \%$ of the inhabitants participated in different cultural events), compared with Sectors 5 and 3 (e.g. 1.1\%).
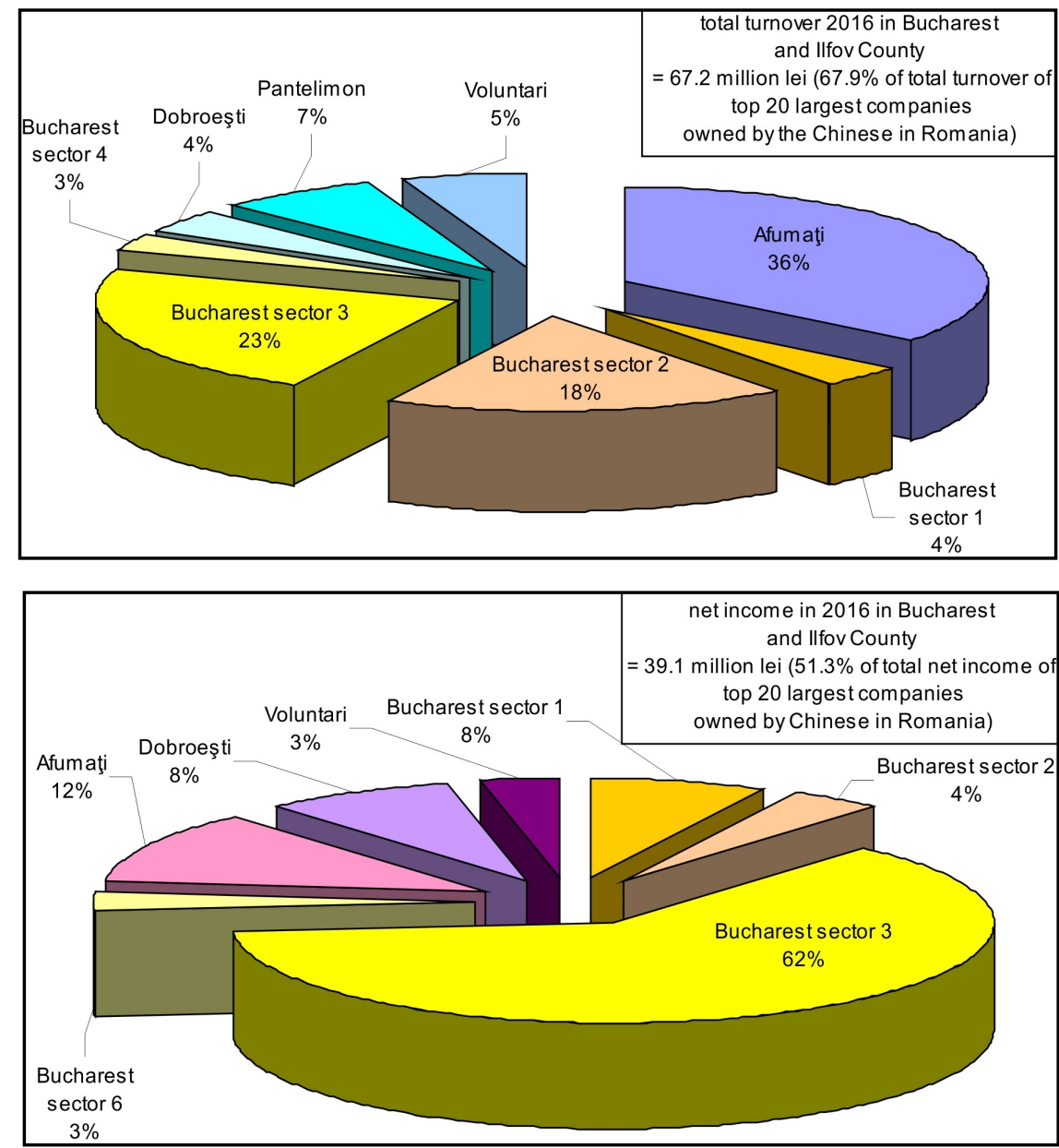

Fig. 7 - Turnover and net income in 2016 - territorial distribution in Bucharest
and in Ilfov County

Source: National Trade Register Office (ECONOMICA.net 2017); data processed by the authors

Monitoring the public information data-base of Sector 2 Mayoralty during the field investigation, some concrete actions were identified targeting the Chinese minority, which might be assimilated as some socio-cultural and institutional hallmarks: (i) the first Chinese language teaching school in Bucharest is functioning within the "Pantelimon" Complex for Recreational Activities and Education; (ii) the educational offer of School No. 46 includes Chinese language courses for the Romanian pupils in the gymnasium cycle; (iii) since 2013, on the initiative of the Bucharest "Confucius" Institute, the Economic College "A. D. Xenopol", introduced the Chinese language as a study-discipline for 120 pupils (Fig. 8); (iv) the Bucharest Police Department had the initiative to employ Chinese persons at the police stations in three Sector 2 departments (public order patrol/prevention, economic police, thefts and robberies). These 
field notes indicate that the local authorities and the public institutions of Sector 2 are aware of the importance of creating and maintaining social relations with and for the Chinese ethnical minority. Also, the Chinese part manages at least two organizations which support cultural and economic activities and initiatives in Bucharest (as well as in Romania): The Romanian Chinese House (the Friendship Association, located in Sector 2) and The Confucius Institute of the University of Bucharest (located in Sector 1, Bucharest), as part of Hanban - the headquarters of the Confucius institutes over the world.

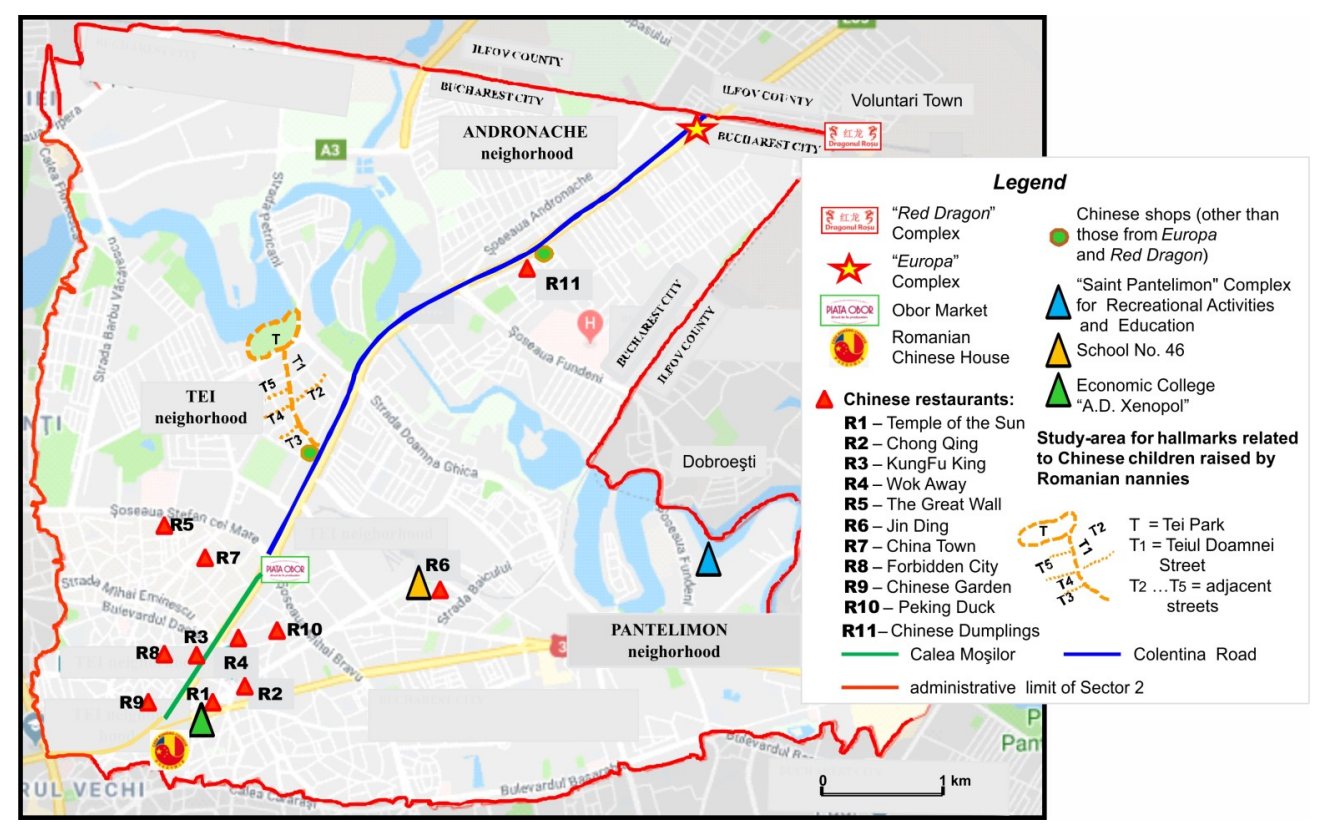

Fig. 8 - The Chinese minority in Bucharest - territorial, economic and socio-cultural hallmarks mapped within Sector 2

Source: authors' content on Google Maps

The field research and notes offer the possibility to sketch and analyze three types of hallmarks related to the social and cultural urban life of the Chinese minority in Bucharest, to the urban territory and to some aspects of the urban local economy (Fig. 9).

The locations of Europa commercial centre in Sector 2 and of the Red Dragon in the neighbourhood rural settlement of Dobroeşti (Ilfov County) represent the territorial hallmarks of the Chinese group in this part of the Capital City. Those two "signs" in the urban and rural tissue have influences on the everyday life of both the Chinese minority and the Romanian majority. The Red Dragon represents a vast commercial complex, formed of 10 "pavilions" hosting 5500 shops in a $500000 \mathrm{~m}^{2}$ built-area. The Chinese residents make daily journeys to Europa and the Red Dragon for their own business while many Romanians frequently shop in these two trade centres as this area benefits from good public and private transportation (a tramway line and three bus lines continued with other five minibus routes).

The Chinese shops in the streets and boulevards of Sector 2 are not very numerous because they are territorially concentrated in Europa and Red Dragon commercial centres. However, several Chinese shops are mapped on the Colentina Boulevard - one of them (25B Colentina 
Boulevard), showing visible signs of deterioration (a pagoda ornamental roof almost completely destroyed), commercialises Chinese traditional objects (decorative vases, Chinese fans, jewellery, etc.).

The presence of Chinese restaurants in Sector 2 constitutes another territorial hallmark which changes the ordinary street landscape, conferring to it a locally Asian "reach". This Asian "air" is not necessarily in accordance with the urban landscape of the old city of Bucharest, or with the place that some historical buildings should occupy in the cultural, historical and architectural patrimony of Bucharest (e.g. one of the Chinese restaurants, located in Mihai Eminescu Street, operates in the house where the concert piano player Cella Delavrancea lived).

The hallmarks related to the local urban economy are deeply interlinked with the presence of Europa and Red Dragon commercial centres. Europa represents an urban landmark of consumption (Asociaţia Mişcarea pentru Acţiune şi Iniţiativă Europeană 2015), this statement being true also for the Red Dragon commercial centre. As already mentioned, the Red Dragon is not located in Sector 2, but nearly its administrative limit, impressing strong traces in the economic life of the Chinese minority and also of the Romanian locals in the Sector 2 of Bucharest. Unfortunately, the economic activities unfolded by the Chinese businessmen within Europa and Red Dragon commercial centres have as hallmak the fraudulent transactions in the supply of goods and merchandise without adequate documents - e.g. the most recent event (on March, 11, 2019), under the "Integrum" operation, unfolded by the National Agency for Fiscal Administration, referred to a total of 105 inspectors from the General Anti-Fraud Directorate who sealed 1038 storage goods facilities in the Red Dragon centre (Mediafax 2019).

Other economic hallmarks are linked with the Chinese companies which activate in Sector 2. A Chinese company (engaged in the repair and maintenance of all types of computers and peripheral equipments) concentrates $37.4 \%$ of the total turnover declared by the Chinese companies located in Bucharest and a single Chinese firm, activating in the wholesale trade and electricity, cumulates only $5.2 \%$ of the total net income registered by the Chinese companies located in Bucharest.

In the three supermarkets located along the Colentina Boulevard (two Carrefour and one Kaufland), the Chinese people use to shop frequently (weekly and even daily) and in large quantities, buying all kinds of products, but especially several products traditionally associated to the Chinese type of consumption (e.g. rice, sesame oil, vegetables such as Chinese cabbage, kohlrabi, different kinds of meat, Chinese spices). Despite the fact that the representatives of these supermarkets declared that there is no special supply for meeting the particular Chinese demands, this commercial behavior was highlighted during a long-time observation period in these three supermarkets.

The hallmarks related to the social and cultural urban life are reflected by the presence of the Chinese people on the streets, in parks, in some kindergartens and in some healthcare units. In their everyday life, the Chinese interact with the locals: their economically active life takes place in Europa and the Red Dragon, where the main customers are Romanians. Regarding their family life, the adults live with other Chinese families, their own children being raised by Romanian nannies within Romanian families.

Particular hallmarks emerged from a special relationship between the Chinese children and their Romanian nannies - a showcase from Tei neighborhood (Sector 2, Bucharest)

The field investigation within the study-area (e.g. Teiul Doamnei Street and the adjacent 
streets, Tei neighborhood) offered the opportunity to reveal some special territorial, economic and socio-cultural hallmarks related to the Chinese children and their very earlier years of childhood within the Romanian families. The concrete situation of Chinese families, with both parents fully engaged in trade activities, represents a constraint for the pursuit of everyday life (Eyles 1989) and it implies the identification of a solution for their own children's raising and early education. The Chinese parents' socio-economic statute (e.g. fully engaged in commercial activities, their income allowing paying a permanent nanny for their child) and cultural behaviour let them choose a Romanian nanny for raising their own children: the Romanian nanny is full-time involved in the Chinese child-care, meaning day and night, seven days per week and almost twelve months per year (only a few leisure days, during the Chinese celebrations, family events and journeys to China). Given the permanent and diverse interactions between the Chinese children and their Romanian nannies, the hallmarks identified are deeply traced in the urban everyday life of the Chinese children, the respective nanny and her family, and, not least, of the Chinese parents. These everyday life evidences are approached in terms of territorial, economic and socio-cultural characteristics.

The territorial traces of Chinese children involve daily routes to the kindergartens (there are three in the study-area, each of them registering Chinese children in all age-cycles), frequent walkings in the neighbouring parks and occasionally travels to different neighbourhoods of Bucharest or to other rural or urban settlements in Romania. The hallmark in terms of economic aspects is materialised by the additional income at the nanny's family budget. As a result of the relationship between the Chinese children and their Romanian nannies, some socio-cultural hallmarks have been also identified. Within the everyday local urban life and in the nanny's family and household, the Chinese child has the occasion to socialise, to develop various interpersonal relations with other Romanian children (e.g. in the kindergarten, parks and on the neighborhood's streets) and adults (e.g. in the general practitioner's consulting room and in the kindergarten). The cultural traces involved by the Chinese childcare come especially from the nannies: evidently, the Romanian nannies do not speak Chinese, so the games, songs and poetry for children are learned in Romanian, while the Chinese children are developing skills to communicate into Romanian. Thus, they make this language more familiar to their Chinese parents, who, generally, have communication problems in the Romanian language. Also, several socio-cultural hallmarks are related to food/nutrition (generally, these Chinese children have Romanian meals, and only occasionally Chinese food, during the visits to their parents' home), education (within the Romanian public education system), health-care (within the Romanian public health-care system), and with playing and spending the leisure time within the Romanian neighbourhood.

\section{Conclusions}

Based on the present stage of knowledge related to the various hallmarks linked to the presence of the Chinese minority within Romanian urban areas, the research conclusions can approach different aspects. So that, the national level information shows that the official number of the Chinese population in Romania decreased by $10.3 \%$ between the 2002 and the 2011 censuses. This trend was accompanied by a change in terms of territorial preferences, related to economic interests. The analyses at county and local levels reveal that the location of two large trade centres (Europa and Red Dragon) on the northeastern outskirts of Bucharest induces major spatial reconfigurations of the Chinese group. In other words, the economic hallmark influences and shapes the territorial traces of the Chinese minority, and implicitly several other socio-cultural signs in the everyday urban life. The territorial and economic hallmarks in the study-area have emerged from the approach of socio-cultural traces. The Chinese parents' everyday life strategy to solve the complex and important issue of raising and educating a child consists in hiring (without legal forms) a Romanian nanny. Thus, the various deep-going relationships established between the Chinese children and their Romanian 
nannies reveal the mutual cultural influences and also, their interlinked reflections in the urban tissue, in the street landscape and in the everyday urban life. So, this territorial level of analysis reveals unexpected and interesting hallmarks imprinted on places and locals, somehow or other, linked to the Chinese minority in Bucharest.

The Chinese represent a closed community in Romania, only their everyday ecommercial activities, administrative and basic services (e.g. healthcare, education) being opened towards the Romanian majority; their personal relationshisps are running predominantly within their own ethnical group. A distinctive place within these relationships is that established between the Chinese children and the Romanian nannies committed to their growth and education. In this way, some connections are established between the Chinese and the Romanians in which the Chinese children represent a sort of driving force which would make the integration of the Chinese minority into the Romanian majority easier if the intention and interest for it would exist.

Approaching the issues of territorial, economic and socio-cultural hallmarks related to the Chinese people's presence in certain places of Romania suggests several other future potential research topics in various geographical branches (e.g. urban and rural, economic and demographic issues). Also, the issues emerged from the study of social and cultural hallmarks deserve a special interest from the researchers activating in the fields of social and cultural geography.

\section{Acknowledgements}

The research for this paper was conducted under the research plan of the Institute of Geography, Romanian Academy: "Geographical Studies on Population Dynamics in Romania".

\section{References}

ADLER P. A., ADLER P. (1994), Observational techniques, in: Denzin N. K., Lincoln Y. S. (eds.), Handbook of qualitative research, SAGE Publications, Thousand Oaks, CA, pp. 377 392.

ALEXE I., PĂUNESCU B. (coord.) (2011), Studiu asupra fenomenului imigraţiei în România. Integrarea străinilor în societatea românească (Study on immigration in Romania. Foreigners integration in the Romanian society), Fundaţia Soros România, București.

ASOCIATIIA MIŞCAREA PENTRU ACŢIUNE ŞI INITTIATIVĂ EUROPEANĂ' (2015), Fişă de comunitate: Chinezi - Date generale și demografice (Community sheet: The Chinese General and demographic data), Retrieved from: www.newminorities.com.

BĂNCILĂ A. M. (2010), Colentina, Turnul Babel al României (Colentina, the Babe Tower of Romania), Migrant în România 7, 12-13.

BAKER L. M. (2006), Observation: A Complex Research Method, Library Trends 55 (1), 171-189.

BAYCAN LEVENT T., MASUREL E., NIJKAMP P. (2003), Diversity in entrepreneurship: ethnic and female roles in urban economic life, International Journal of Social Economics 30 (11), 1131-1161.

BIZBRAŞOV (2018), Investiţia de 20 de milioane de euro în producţia de tractoare chinezeşti la Râşnov a intrat în faliment (The 20 million Euro investment in the production of Chines trucks in Râsnov went bankrupt), Retrieved from: www.bizbrasov.ro.

CASABURI I. (2017), Chinese investment trends in Europe: 2016-17 Report, ESADE China Europe Club, Retrieved from: www.esadeknowledge.com.

CHAN W. Y., KOH Y. S. (eds.) (2018), New Chinese Migrations: Mobility, Home and Inspirations, Routledge, London and New York.

CHEN X. (2010), Souls in exile: A study of Chinese migration workers in Romania, ILO Office for China and Mongolia, Beijing.

CHUN A. (2017), Forget Chineseness: On the Geopolitics of Cultural Identification, 
SUNY Press, New York.

COSGROVE D. (1989), Geography is everywhere: culture and symbolism in human landscapes, in: Gregory D., Walford R. (eds.), Horizons in Human Geography. Horizons in Geography, Palgrave, London, pp. 118-135.

CRETAN R., TURNOCK D. (2008), Romania's Roma population: from marginality to social integration, Scottish Geographical Journal 124 (4), 274-299.

CRETAN R., POWELL R. (2018), The power of group stigmatization: wealthy Roma, urban space and strategies of defence in post-socialist Romania, International Journal of Urban and Regional Research 42 (3), 423-441.

CROWTHER D., LANCASTER G. (2014), Research Methods: A concise introduction to research in management and business consultancy, Routledge, New York.

DRAHOKOUPIL J., KIROV V., MUNTEAN A., RADU E. (2017), Chinese investment in Romania and Bulgaria, in: Drahokoupil J. (ed.), Chinese investment in Europe: corporate strategies and labour relations, European Trade Union Institute, Brussels, pp. 141-154. ECONOMICA.NET (2017), Chinezii care fac cei mai mulţi bani în România. Top 20 de companii (The Chinese who make the most money in Romania), Retrieved from: www.economica.net.

EYFERTH J. (2012), Women's Work and the Politics of Homespun in Socialist China, 1949-1980, International Review of Social History 57 (3), 365-391.

EYLES J. (1989), The Geography of Everyday Life, in: Gregory D., Walford R. (eds.), Horizons in Human Geography. Horizons in Geography, Palgrave, London, pp. 102-117. FEATHERSTONE M. (2000), Undoing Culture: Globalization, Postmodernism and Identity, SAGE Publications, London. London. FRIEDMAN J. (1994), Cultural Identity \& Global Process, SAGE Publications, GORMAN G. E., CLAYTON P. (2004), Qualitative research for the information professional: A practical handbook, Facet, London. HOLMÉN H. (1997), Limits to Globalization, European Review 5 (1), 75-87.

HUANG P. C. C. (2011), The Modern Chinese Family: In Light of Economic and Legal History, Modern China 37 (5), 459-497.

HUANG P. C. C. (2012), Profit-Making State Firms and China's Development Experience: "State Capitalism" or "Socialist Market Economy"?, Modern China 38 (6), 591-629. HUI E. S. I. (2018), Hegemonic Transformation: The State, Laws, and Labour Relations in Post-Socialist China, Palgrave MacMillan, Basingstoke.

IANOŞ I., TĂLÂNGĂ C. (1994), Oraşul şi sistemul urban românesc în condiţiile economiei de piaţă (The Romanian city and urban system in the market economy conditions), Institute of Geography, Romanian Academy, Bucharest.

IANOŞ I. (2004), Dinamica urbană. Aplicaţii la oraşul şi sistemul urban românesc (Urban Dynamics. Applications to the Romanian city and urban system), Technical Press House, Bucharest.

IANOŞ I., HELLER W. (2006), Spaţiu, economie şi sisteme de aşezări (Space, Economy and Settlements Systems), Technical Press House, Bucharest.

IANOŞ I., SîRODOEV I., PASCARIU G., HENEBRY G. (2016), Divergent patterns of built-up urban space growth following post-socialist changes, Urban Studies 53 (15), 31723188.

INSTITUTUL NAȚIONAL PENTRU CERCETARE ȘI FORMARE CULTURALĂ (2015), Studiu de consum cultural la nivelul orașului București (Cultural consumption study for Bucharest), Retrieved from: www.strategiaculturalabucuresti.ro.

JACOBY W., KORKUT U. (2016), Vulnerability and Economic Re-orientation: Rhetoric and in Reality in Hungary's "Chinese Opening", East European Politics and Societies: and Cultures 30 (3), 496-518.

KAPLAN D. H. (1998), The Spatial Structure of Urban Ethnic Economies, Urban Geography 19 (6), 489-501. KAPLAN D. H., LI W. (eds.) (2006), Landscapes of the Ethnic Economy, Rowman \& 
Littlefield Publishers, Inc., New York.

LI W. (1998), Anatomy of a New Ethnic Settlement: The Chinese Ethnoburb in Los Angeles, Urban Studies 35 (3), 479-501.

MÁLOVICS G., CRETAN R., MÉREINE-BERKI B., TÓTH J. (2019), Socioenvironmental justice, participatory development, and empowerment of segregated urban Roma: Lessons from Szeged, Hungary, Cities 91, 137-145.

MAYORALTY OF SECTOR 2 (2017), Strategia de dezvoltare locală integrată şi durabilă Sectorul 2 2016-2025 (Integrated and Sustainable Local Development Strategy of Sector 2, Bucharest, for the period 2016-2025), Retrieved from: www.ps2.ro.

MCCALEB A., SZUNOMÁR Á. (2017), Chinese foreign direct investment in central and eastern Europe: an institutional perspective, in: Drahokoupil J. (ed.), Chinese investment in Europe: corporate strategies and labour relations, European Trade Union Institute, Brussels, pp. 121-140.

MCFARLANE C. (2006), Transnational development networks: bringing development and postcolonial approaches into dialogue, The Geographical Journal 172 (1), 35-49.

MEDIAFAX (2019), Operaţiunea „Integrum”: Inspectorii antifraudă au sigilat peste 1.000 de depozite din complexul comercial Dragonul Roşu („Integrum” Operation: Anti-fraud inspectors sealed over 1000 deposits of the Red Dragon commercial complex), Retrieved from: www.mediafax.ro.

MEN J. (2012), The EU and China: mismatched partners?, Journal of Contemporary China 21 (74), 333-349.

MÉREINÉ BERKI B., MÁLOVICS G., TÓTH J., CRETAN R. (2017), The role of social capital and interpersonal relations in the alleviation of extreme poverty and spatial segregation of Romani people in Szeged, Journal of Urban and Regional Analysis 9 (1), 33-50.

MIONEL V. (2019), From Religious Segregation to Cultural Heritage. The Case of Armenian Community in Bucharest, Journal of Urban and Regional Analysis 11 (1), 69-86.

MULHALL A. (1998), Methods of data collection for quantitative research, in: Roe B., Webb C. (eds.), Research and Development in Clinical Nursing Practice, Whurr Publishers, London, pp. 135-169.

MULHALL A. (2003), In the field: notes on observation in qualitative research, Journal of Advanced Nursing 41 (3), 306-313.

NYíRI P. (2007), Chinese in Eastern Europe and Russia: A Middleman Minority in a Transnational Era, Routledge, New York.

ONDREICSIK A.-T. (2012), The New Minority: A Case Study of Chinese Immigrants to Romania, University of Amsterdam, Retrieved from: www.scripties.uba.uva.nl.

PAVLIĆEVIĆ D. (2018), 'China Threat' and 'China Opportunity': Politics of Dreams and

Fears in China-Central and Eastern Europe Relations, Journal of Contemporary China 27 (113), 688-702.

PĂCURAR A. (2004), Noile minorităţi din România (New minorities in Romania), GeoPolitica 2 (4-5), 62-72.

PENCEA S. (2017), Romania-China Trade and Investment Relations Against the

Backdrop of "One Belt, One Road" Strategy, Romanian Economic and Business Review 12 (2), 17-28.

PENCEA S., OEHLER-ŞINCAI I. M. (2014), Chinese Outward Direct Investment in Central and Eastern European Countries. A Romanian Perspective, Romanian Economic Business Review 9 (2), 45-72.

PETSIMERIS P. (1998), Urban Decline and the New Social and Ethnic Divisions in the

Core Cities of the Italian Industrial Triangle, Urban Studies 35 (3), 449-466.

PIEKE F. N. (2012), Immigrant China, Modern China 38 (1), 40-77.

ROBERTSON R. (2000), Globalization: Social Theory and Global Culture, SAGE Publications, London.

SALMON J. (2015), Using observational methods in nursing research, Nursing Standard 29 (45), 36-41. 
SĂGEATĂ D.-R. (2014a), The Urban Systems in the Age of Globalization. Geographical Studies with focus on Romania, Lambert Academic Publishing, Saarbrucken.

SĂGEATĂ R. (2014b), Globalisation and Urban Spatial Reconversion. Case-Study: Commercial Services in Romania, Forum Geografic 13 (1), 91-100.

SĂGEATĂ R. (2014c), Globalization and New Ethnic Minorities in Romania, in: Mihaylov V. (ed.), Territories and Identities in Central, Eastern and Southeastern Europe, Institute of Geopolitics, Częstochowa, pp. 258-270.

SĂGEATĂ R. (2015), Emigraţia chineză, GeoPolitica 62 (4), 1-15.

SĂGEATĂ R. (2017), Recent Changes in Romania's Ethnical Structure. The Chinese Minority - A Case Study, Rev. Roum. Géogr./Rom. Journ. Geogr. 61 (1), 69-78.

SCHREIBER E. W., RAULARIAN R., MAN T. (2017), National Minorities in Romania. Their Present Demographic and Political Situation, ISR-Forschungsbericht 42, 439-446.

SPRADLEY J. P. (2016), Participant observation, Waveland Press, Inc., Long Grove, IL. TOADER Ş. (2012), Cazul foştilor lucrători chinezi care au solicitat azil în România (The case of former Chinese workers who asked for asylum in Romania), in: Blocul Naţional Sindical, Străinii din România. Descrieri, analize şi dialoguri pe tema imigraţiei, Retrieved from: www.criticatac.ro.

UNGUREANU A., IANOŞ I. (1996), Characteristic features of the urban system in Romania, Revue Roumaine de Géographie 40, 3-12. VANGELI A. (2018), Global China and Symbolic Power: The Case of $16+1$ Cooperation, Journal of Contemporary China 27 (113), 674-687.

VAN KEMPEN R., ÖZÜEKREN A. Ș. (1998), Ethnic Segregation in Cities: New Forms and Explanations in a Dynamic World, Urban Studies 35 (10), 1631-1656.

VESALON L., CRETAN R. (2019), "Little Vienna" or "European Avant-Garde City"? Branding Narratives in a Romanian City, Journal of Urban and Regional Analysis 11 (1), 19-34. WUNDRAK R. (2007), Immigration During the Wild Years: Chinese Pioneers in Bucharest, The Romanian Journal of European Studies 5-6, 135-151.

WUNDRAK R. (2010), Die chinesische Community in Bukarest: Eine rekonstruktive, diskursanalytische Fallstudie über Immigration und Transnationalismus, VS Verlag für Sozialwissenschaften, Wiesbaden.

YANG K., ORTMANN S. (2018), From Sweden to Singapore: The Relevance of Foreign Models for China's Rise, The China Quarterly 236, 946-967.

ZHAO S. (2010), The China Model: can it replace the Western model of modernization?, Journal of Contemporary China 19 (65), 419-436.

ZIARUL FINANCIAR (2017), Chinezii de la Huawei Technologies vor să ajungă la 1.550 de angajaţi în birourile din Bucureşti până la finalul anului (The Chinese from Huawei Technologies aim to reach 1550 employees in their Bucharest offices by the end of the year), Retrieved from: www.zf.ro.

ZIARUL FINANCIAR (2018), Eurosport DHS a ajuns la 400 de angajaţi în fabrica de biciclete din Deva şi mai recrutează încă 100 de oameni (Eurosport DHS reached 400 employees in their bicycles factory from Deva and they are recruiting another 100 people), Retrieved from: www.zf.ro.

Initial submission: 04.04.2019

Revised submission: 12.08.2019

Final acceptance: 26.09 .2019

Correspondence: Institute of Geography, Romanian Academy, 12 Dimitrie Racovita Street, 023994, Sector 2, Bucharest, Romania.

Email: rsageata@gmail.com 